\title{
WASTE AND POLLUTION IN THE ANCIENT ROMAN EMPIRE ${ }^{1}$
}

\author{
FILIP HAVLÍČEK ${ }^{1}$, MIROSLAV MORCINEK $^{2}$ \\ ${ }^{I}$ Department of Environmental Studies, Masaryk University, Brno, Czech Republic \\ ${ }^{2}$ Department of Classical Studies, Masaryk University, Brno, Czech Republic
}

\section{Мотто}

The sea is like history - when viewed in perspective it looks monumental, but when you are in the middle of it, it will make you sick to your stomach.

Gabriel Laub

History doesn't repeat itself, but it does rhyme.

Mark Twain

Received: $29^{\text {th }}$ August 2016, Accepted: $12^{\text {th }}$ September 2016

\section{Abstract}

This article describes select examples of waste management from the Roman Empire (27 BCE to $365 \mathrm{CE}$ ). Classical written sources and anthropological and archeological literature were studied. The central theme of this paper is ancient man's relationship with waste and his responses to pollution.

Key words: Roman Empire, waste, pollution, sewerage, city, written sources, archeology, anthropology

\section{INTRODUCTION}

Waste management is a topic frequently bandied about in today's world. However, interest in environmental problems is not just a modern phenomenon; people were concerned with similar issues in the past, including the preindustrial era. The Roman Empire, even though people today find it ever more distant form our times, still attracts great attention. Its attractiveness can be attributed to the fact that it is still viewed as one of the pillars of Western civilization.

The Roman Empire is frequently compared with our modern world and parallels between the two are being highlighted. ${ }^{2}$ The ancient Romans are normally portrayed as bearers of advanced science and technology. These reflections include the notion that there was a high level of public hygiene, represented by Roman aqueducts (Fig. 4), baths, sewage systems,

\footnotetext{
${ }^{1}$ This publication was written at Masaryk University as part of the project Current approaches to the study of environmental phenomena, MUNI/A/1299/2014 (from ISEP) with the support of the Specific University Research Grant, as provided by the Ministry of Education, Youth and Sports of the Czech Republic in the year 2015.

${ }^{2}$ It is worth mentioning that the Roman Empire had a larger land area in some decades than the European Union has today.
} 
and toilets. But due to the mere existence of these things, can we automatically come to such conclusions? How did inhabitants of the Roman Empire deal with waste?

Cleary, in the Roman era waste was not created in the quantities it is today. The population was much smaller than today. Most households could only afford humble furnishings; many objects were used as long as possible. The mega-production of packaging that we know so well did not exist; non-biodegradable materials were an unknown phenomenon (Weeber, 2006). In comparison with earlier civilizations, it can be expected that Rome, with its increasing urbanization, also produced higher amount of waste. This idea is generally valid for ancient urban civilizations as opposed to cultures at a lower stage of technological development. Considering supposed advancement of the Roman Empire, it could be assumed that at least leading authorities would be able to deal with waste better than their Greek and Mesopotamian predecessors. ${ }^{3}$

The research question we would like to address in this study is, how was waste, including waste water, managed in the Classical era, and how did this management manifest itself in practice in the overall relationship between the people living in the Classical era and the environment? This topic is directly connected to general perceptions of cleanliness and hygiene that are reflected in the practices and rituals of a given group or culture.

In this article we will cover waste management, concepts of cleanliness, and the relationship with water, using various examples from the Roman imperial period. This article is more descriptive in nature because to begin ab ovo would entail a scope beyond the capacity of this article. Therefore, we will not describe in great detail hypotheses on how concepts of cleanliness and hygienic rules arose (I attempted to do so in Havlíček, 2015), but we will describe examples of how this fact played out in reality. Nonetheless, we cannot avoid a brief excursion into the causalities of evolutionary biology. Undoubtedly much more work will need to be done until we are able to understand this phenomenon in its full complexity.

We will focus on the urban environment (including that of Rome itself), that is, the main producer of waste. We shall leave aside military camps, the countryside, and mining operations. At the center of our interest is the pollution caused by waste, the fight against it, and new problems arising as a result. Since there is a great geographical difference between territorial holdings of the Empire and a nature of the cities we do not want to generalize ${ }^{4}$. We illustrate the phenomena using unique examples of waste management that are recorded in archeological as well as written sources that we have accessed through the latest secondary literature.

In 1945 American anthropologist George P. Murdock presented a long list of characteristics that can be observed in all cultures known from history and anthropology (Murdock, 1945). One of these universals is cleanliness, a concept that is tightly linked to waste management. On the basis of this hypothesis, we will consider waste management (a clear consequence of the human tendency for cleanliness) to be an anthropological (or biological) constant, from which many local (cultural) variants have arisen, which have, over time, branched out into many different practices, rituals, measures, and rules. All members of the Hominidea family are sensitive to contact with dirt, slime, and stickiness

\footnotetext{
${ }^{3}$ From the perspective of materials and technology, the Classical era was a de facto continuation of the Iron Age with its high energy demands associated with producing this material. As unbelievable as it may sound, the enormous slagheaps near the cities of Vetulonia and Populonia were used by the Italian arms industry during World War I material shortages (Jelínek et Kysučan, 2014).

${ }^{4}$ Roman cities variate from towns along the river systems and in close connection to the Mediterreanean and Black sea to towns in the interior and further north.
} 
(Smith, 2007). Labelling this attitude an anthropological constant demonstrates the fact that this phenomenon, just like the manufacture of tools (we could speak here about the extended phenotype that occurs in Homo sapiens; Dawkins, 1999), and a certain need for religion, is shared by all cultures, both historical and contemporary. According to Norbert Elias acquiring hygienic habits is one of the initial stages of human civilization and in the gradual bio-psychological formation of human habits and morals (Elias, 2000 in Smith, 2007). Let us examine to what extent ancient Romans followed these patterns.

In the broadest perspective, it is necessary to view concern for cleanliness and the related phenomenon of waste management as an evolutionarily beneficial model of human nature. Aversion to dirtiness or bad odors triggers our evolutionarily developed receptors that promptly react and relay any necessary information to the brain, which subsequently assesses the next course of action. It is our insular cortex that informs us about smells; when this part of the brain functions improperly, it results in obsessive compulsive disorder (William, 1997). On the other hand, neglecting personal hygiene is often a sign of clinical depression (Smith, 2007). It should be noted that humans' relationship with cleanliness and disorder are to a large extent culturally determined (Douglas, 1966).

\section{The City-A Layered Organism Living from the Presence OF PeOPLE}

Water, an irreplaceable commodity in every human settlement, was transported to cities such as Rome ${ }^{5}$ by aqueducts from sources that could be many dozens of kilometers away. ${ }^{6}$ Here, water was delivered through pipes that were often made of lead; for distributing water in the cities smaller-gauged ceramic, wooden, and leather pipes were used (Adkins et Adkins, 2004). According to estimates, Rome was supplied with approximately half a million to one million cubic meters of water per day (Evans, 1997). The aqueduct system worked on the very simple principle of gravitational force. If a valley or lowlands stood in the path of the aqueduct, such an obstacle could be overcome by bridgework that did not disrupt the water's naturally downward flow and which maintained the proper water pressure; water was ideally transported to the highest point in a city (in some cases a system of high-pressure pipes was used to siphon water across such areas). Along the way, water was purified in settlement ponds, from where it then flowed into a main reservoir and was further distributed throughout the city (Adkins et Adkins, 2004). Aqueducts were, of course, directly linked to the issue of sewerage, considering the fact that water transported via an aqueduct could not be stopped but only diverted elsewhere. Despite the advanced nature of the sewer system and waterworks of ancient Rome, we cannot assume that all citizens had a right to this privilege. Whether a person was connected to the water or sewage system reflected their social status. As Smith writes: "You were nothing in Rome without your expensively plumbed latrines, courtyard fountain, pool, or private baths...” (Smith, 2007; 105).

\footnotetext{
${ }^{5}$ Instead of hard-to-build aqueducts, in urban environments such as in Londiun (today's London) wells were often used as sources of drinking water (Blair et al., 2006). Building these waterworks was necessary due to the city baths' enormous water demands. Although waterworks brought a significant amount of water to Rome, it cannot be assumed that everyone had access to it. Poor neighborhoods, even in the "age of the aqueduct," were dependent upon water from rivers, springs, wells, and rainwater reservoirs (Smith, 2007). However, it is necessary to add that even poor Romans living in apartment buildings that lacked infrastructure or even those living on the street could draw water for free from public fountains, visit baths, etc. No segregation existed here.
}

${ }^{6}$ Connecting to the water system was no exception - the price of water was based on water pipe radius. The calix, Latin for bowl or cup, was used as the unit of measure (Adkins et Adkins, 2004). 
Many ancient cities also had drainage systems that drained wastewater from bathrooms and kitchens. Solid waste was stored in cesspits or was used as fertilizer. It was not compulsory to be connected to this drainage system; being connected to the public sewage system was a paid service. For buildings that were not connected, a private service existed in which someone came to the building each day to collect clay waste vessels, the contents of which were sold to farmers outside of the city. Conditions, however, varied throughout the empire. For example, in Pompeii, buckets containing waste and fecal matter were thrown out of windows onto the street, where it collected and rotted. In places that were not connected to a waste system, there was little care about waste management. Stepping stones for pedestrians document this fact. Such contamination supported the spread of epidemics. According to Hughes, the Tiber River in Rome was highly polluted; waste material was often disposed of in its waters (Hughes, 2001). During the reigns of Augustus and Aurelian the Tiber was cleaned and its channel widened. Augustus even established a body for inspecting the river channel and banks; during Trajan's reign its competences grew to include managing the sewage system (Hughes, 2001).

The Roman Empire was most likely the first civilization in Europe to have on organized urban waste management labor force, already in the fourth century BC (Vesilind et al., 2002). Work was carried out by a cleaning crew, who loaded piles of waste onto horse-drawn wagons using shovels. Waste was taken either outside city gates or somewhere else far from civilization (Pichtel, 2005). City authorities could impose fines for the improper disposal of waste. A board informed citizens not to leave waste in the street and indicated where they should go to dispose of it (Kelly, 1973). In another step serving to keep the city clean overall, Emperor Vespasian (AD 69-79) ordered the installation of public flush toilets (Kelly, 1973). By AD 300, the number of such facilities in Rome increased to 144 (Bilitewski et al., 1997).

\section{The Roman City-ONE Big LANDFiLL?}

In Rome and other cities in the empire, the approach to waste management was quite lax. The growing population, among other things, contributed to this situation. For example, Rome itself at the end of the Republic had one million inhabitants. ${ }^{7}$ Waste of probably all kinds was thrown out of windows and onto the street, particularly at night (Weeber, 2006). The satirist Juvenalis warns his readers about this phenomenon:

...it's a long way up to the rooftops, and a falling tile

can brain you. Think of all those cracked or leaky vessels

tossed out of windows - the way they smash, their weight,

the damage they do to the sidewalk! You'll be thought most improvident,

a catastrophe-happy fool, if you don't make your will before

venturing out to dinner. Each open upper casement

along your route at night may prove a death-trap:

so pray and hope (poor you!) that the local housewives

drop nothing worse on your head than a pailful of slops.

(Juvenalis, Saturae 3.269-277, transl. by P. Green).

\footnotetext{
${ }^{7}$ Likely data—taken from Thommen 2012: 124.
} 
People let some rubbish lie around on the floors in their home (Thüry, 2001). City streets most likely looked similar, no matter how garbage found its way there. ${ }^{8}$ The poet Martialis provides a description in one epigram:

If I did not wish and deserve to see you at home this morning, Paulus, may your Esquiline abode be further from me than it is. But I am close neighbor to the Tiburtine column, where rustic Flora gazes at ancient Jove. I must surmount the uphill path from Subura with its dirty stones and steps never dry, and I am scarcely able to break through the long trains of mules and the marble blocks you see hauled by many a rope. What is worse still, Paulus, worn out after a thousand labors, I am told by your janitor that you are not at home. Such is the outcome of my vain effort and my poor soaked gown: it would hardly have been worth it to see Paulus of a morning. Shall the faithful client ever be cultivating unconscionable friends? Unless you stay abed, you can be no patron of mine.

(Martialis, Epigrammata 5.22, transl. by D. R. Shackleton Bailey)

Waste pits were located nearby buildings (Weeber, 2006; Thommen, 2012: 128); waste was also thrown into sewers and wells (Thommen, 2012: 106). Human waste was often also discharged into the street (Thüry, 2001:17-21, 25-26).

\section{OFFICIAL AND TEChNicAl MEASURES 9}

These bad habits were tackled through bans and orders, as well as by applying concrete technical measures. Concerning throwing rubbish from windows, the main thing was to prevent pedestrians from being injured. The perpetrator or the building owner could be hit with a fine $^{10}$ (Thüry, 2001: 17; Thommen, 2012: 127-128). Littering was also punishable. Town leaders in Herculaneum put great efforts into maintaining cleanliness on the streets, which were reflected, for example, in a prohibition from throwing rubbish on the ground near public drinking fountains. On an information board located directly near the fountain, town representatives established sanctions for this violation - citizens had to pay a fine and slaves were to be whipped (Thüry, 2001: 15). Private building owners were required to keep the section of street in front of their buildings clean. If they did not do so, they had to pay for it to be cleaned at their own expense ${ }^{11}$ (Weeber, 2006; Thommen, 2012: 127). Aediles and a four-member committee known as quattuor viri viis purgandis were in charge of ensuring clean streets (Weeber, 2006; Thüry, 2001: 13-15). ${ }^{12}$

\footnotetext{
${ }^{8}$ Another source — e.g., Petronius (bleeding feet, shards)--reference in Thüry, p. 24.

${ }^{9}$ For information about measures in general: Weeber 2006, Thüry 2001.

${ }^{10}$ Dig. 9.3.

${ }^{11}$ Dig. 43.10, CIL I 593, lines 24ff.

${ }^{12}$ Emperor Caligula supposedly once expressed indignation with Vespasian - the future emperor then only a mere aedile - for not carrying out his duties ${ }^{12}$ (Thüry, 2001: 13-14).
} 
Solid waste was most likely taken outside of the town. ${ }^{13}$ Although during daytime hours transportation was restricted in the cities, records of exceptions for waste wagons exist (plostra ... stercoris exportandei causa) ${ }^{14}$ (Thüry, 2001: 5-7). ${ }^{15}$ There is, however, no record of a public, organized waste removal service. Waste removal was more an individual effort (Thüry, 2001: 5-9). ${ }^{16}$ In any case, such work was likely done by people of lower social status, mostly slaves. ${ }^{17}$ In is not known exactly where this waste was actually taken. Outside of towns, just like in the countryside or nearby military camps, ${ }^{18}$ dumps and waste pits ${ }^{19}$ were established (Weeber, 2006; Thommen, 2012: 128).

A special, well-known example is Monte Testaccio ${ }^{20}$ (Figs. 5, 6, 7, 8, 9). A mere two kilometers from the now-silenced heart of the Roman Empire, the Roman Forum, lies a noticeable mound. This artificial hill, the largest preserved waste heap from Classical times, is the result of a specific waste management practice. The entire mound consists almost entirely of broken amphorae imported to Rome ${ }^{21}$ as olive oil containers (testae-from the Latin for fragments of bricks, vessels, etc.) (Peña, 2007). Most likely these vessels could not be reused or recycled in any meaningful, economic fashion. It simply was not worth transporting the extremely large (70 1, Dressel 20 type), dirty amphorae back to where they came from. Thus, they were smashed and deposited at this dump (Claridge et al., 1998). ${ }^{22}$ This dump was in operation approximately from the first century BCE to the third century CE. ${ }^{23}$ The entire area of the heap, 20,000 $\mathrm{m}^{2}$ (approximately 600,000 $\mathrm{m}^{3}$ ) consists of millions of amphorae (estimates vary from 30 to 50 million). ${ }^{24}$ In any case, however, it was not a chaotic dump of unusable material. It was based on a well-thought-out system. The material was deposited in terraces, to prevent landslides. In order to prevent the porous,

\footnotetext{
${ }^{13}$ For information regarding technical measures, see Weeber, 2006; Thüry, 2001; Thommen, 2012.

${ }^{14} \mathrm{CIL}$ I 593, lines 66ff (CIL = Corpus inscriptionum Latinarum).

${ }^{15}$ Die Tabula Heracleensis (lex Iulia municipialis?) (vgl. auch Tac. ann. 11,32,3).

${ }^{16}$ Compare with conditions in Greece: Athens featured koprológoi, whose job it was to bring waste ten stadia from towns, (Weeber, 2006).
}

${ }^{17}$ Close physical contact with the bodily waste of other people is generally considered to be revolting in all cultures. Work which involves coming into contact with this material is as a rule carried out by people from lower social classes (cleaners, garbagemen, and sewer cleaners) (McLaughlin, 1973). If you google the term "the worst job in the world," a significant amount of the hits involve cleaning sewers, observing or measuring bodily waste and odors, or jobs at landfills.

${ }^{18}$ The dump discovered by the Vindonissa camp in today's Switzerland is well known.

${ }^{19}$ Even the odd dead gladiator, slayed in the arena, was thrown here.

${ }^{20}$ For a brief description of Monte Testaccio, see Weeber, 2006; see Thüry, 2001: 36-39 for a more detailed description.

${ }^{21}$ The amphorae were mainly from Hispania and North Africa.

${ }^{22}$ There was certainly a general disinterest in recycling. During the entire existence of the dump, it was forbidden to take anything from it; the justification for this ban was that the Romans were so well off economically that they had no need to reuse waste (Thüry, 2001: 37).

${ }^{23}$ Considering the fact that the oldest parts of this mound are in the most poorly accessible places (i.e., at the base of the entire dump), any dating of its establishment is only approximate.

${ }^{24}$ Weeber 2006: der Hügel von 35 m Höhe und 850 m Umfang. 
oil-soaked amphorae from going rancid, sections of the heap were dusted with limestone (Claridge et al., 1998). It is remarkable to note that the entire heap played a social role in the story of Rome, even after it was no longer used for its primary function. Celebrations and ceremonies were held here. For Christians, this artificial hill served as Golgotha on Good Friday (Korn, 2002). In 1849, in fighting against the French army, cannons were placed here to protect the city (Trevelyan, 1907). ${ }^{25}$

In general, storing waste outside of the city only shifted the problem elsewhere. Odours from dumps must have been detectable at the city's edge. Meanwhile, dumps themselves could contaminate the groundwater (Thüry, 2001: 45-46).

\section{Sewerage}

Another way to remove waste from the immediate vicinity of residential spaces were municipal sewer systems. ${ }^{26}$ These systems comprised up to four orders of sewers. First-order sewers drained wastewater from buildings. Far from all buildings, however, had the opportunity to take advantage of this system. ${ }^{27}$ Water and sewerage were paid services and being connected to these systems de facto reflected the social status of residents. For example, the apartment buildings, known as insulae, lacked any such infrastructure. Liquid as well as solid waste was removed in vessels and taken to settlement pits, the closest public latrines, or poured into the sewer (Weeber, 2006; Thommen, 2012: 127). Second-order sewers were made up of underground tubes and open sewers. Rainwater and water flowing permanently from aqueducts flushed waste through troughs (Weeber, 2006).

In Pompeii, however, most household drainage systems drained directly to the street, which itself functioned partially like a sewer. Stepping stones were installed so that people could cross the street without getting their feet wet (Hughes, 2001: 170; Thüry, 2001: 10). Street sewers were connected either to a local stream, a swampy area, or to the sea. Larger towns and cities also had third- and fourth-order sewers-major sewers and collector sewers. $^{28}$

A famous example of a sewer system in the ancient world is the Roman Cloaca Maxima (Fig. 3, Latin for Greatest Sewer), parts of which still function today. Construction began around $600 \mathrm{BC}$ during the reign of Etruscan king Tarquinius Priscus for the purpose of draining swampy lowland areas in the city (to the Tiber River), especially in the area around the Roman Forum, where later one of the most important places in Rome could develop

\footnotetext{
${ }^{25}$ This manner of storing waste is still used today in many landfills. For example, today waste is deposited in terraces at one of the largest landfills in the world, the Puente Hills Landfill in California.

${ }^{26}$ To a lesser extent, sewer systems and pipes (for inflow of clean water and the drainage of dirty water) can be found in Babylonian palaces. Here, wastewater ended up in dung heaps. The Minoan palace at Knossos is often mentioned in connection with waste management because it had an independent wastewater drainage system (Pichtel, 2005).

${ }^{27}$ For a general overview of sewers and waste, see Glaser, 2006; Thüry, 2001: 10-11; Weeber, 2006.

${ }^{28}$ The four categories of the Roman sewerage system according to Brill's New Pauly: Encyclopaedia of the Ancient World:

1st order - initial channels - from various individual building

2nd order - street sewers

3rd order - major sewers

4 th order - collector sewer
} 
(Thüry, 2001: 10). Etruscan combat engineers were used as the labour force. Over the course of the following centuries, the system was expanded and connected to street sewers.

The originally open sewer system was transformed into enclosed channels, with some tunnels reaching up to about $3 \mathrm{~m}$ in width and $4 \mathrm{~m}$ in height (Thüry, 2001: 10; Hopkins, 2007: 1-2). It was therefore possible to conduct inspections in boats. The sewers needed to be checked and cleaned to prevent blockages. Better runoff was achieved on the one hand by flowing water from aqueducts and on the other by construction design elements-for example, smaller sewers flowed into larger ones (Glaser, 2006). It was, however, a struggle that was more or less fought in vain. People overburdened the sewer system with solid waste; latrines and drainage pipes in homes (if there were any) were located near the kitchen, one of the greatest sources of waste. Even the bodies of victims of political murders during times of unrest were allegedly thrown into sewers (Thüry, 2001: 10-13; Thommen, 2012: 106). Another problem the Cloaca Maxima faced was because it flowed into the Tiber, when water levels were high during flooding waste was washed into the streets (Weeber, 2006). It should be mentioned that the Cloaca Maxima, despite its high state of technological development, by far did not have the capacity to drain the entire city, and many cities in the empire had no sewer system whatsoever (Thüry, 2001: 10-11).

\section{Latrines $^{29}$}

Roman towns also featured municipal latrines (Fig. 1, Fig. 2) 2). ${ }^{30}$ They were likely established in the late Republic, and Rome reportedly had 144 of them in later antiquity. (Thüry, 2001: 12; Thommen, 2012: 124). There was an ingenious system for flushing these pit toilets using running water from the baths (Adkins et Adkins, 2004). Clean water constantly ran through the trough at the feet of ancient visitors for soaking sponges that served as toilet paper. Public latrines did not only serve as sanitation facilities, but they were also a place of social meetings and conversation. Those using the latrines were not separated by stalls as they are today, and the interior was richly decorated with marble and mosaics (Hughes, 1996; Adkins et Adkins, 2004). A pit was located under the stone latrines. The seats were either wooden or stone, and seating was open-that is, no stalls separated people (Adkins et Adkins, 2004). There was an ingenious system for flushing the latrines using wastewater from the baths (Adkins et Adkins, 2004). They were clearly designed not just for their primary function as toilets but also as a place for conversation (Hughes, 1996) ${ }^{31}$.

Most inhabitants however used chamber pots or jugs that were taken along with waste outside of the house, ${ }^{32}$ or continued to heed the call of nature on the street (Thommen, 2012: 127). Many prohibitions are evidence of this; perpetrators were threatened with the wrath of the gods. On one relief discovered in Aquileia, Jupiter is depicted casting lightning bolts at one such sinner (Thüry, 2001: 17-19).

By analyzing the content of latrines we can discover detailed information about the diets of the lower and middle classes. On 14 August 79 CE Mount Vesuvius buried the area around the Gulf of Naples in a hot layer of volcanic ash. Thanks to this tragic event, we have learned a great amount of information about daily life in the towns near Vesuvius (Parslow, 1995).

\footnotetext{
${ }^{29}$ For general discussions of latrines, see Höcker, 2006 and Neudecker, 1994.

${ }^{30}$ More than 80 latrines were discovered in Herculaneum.

${ }^{31}$ Emperor Vespasian faced criticism when he introduced a tax for using these public toilets, which allegedly became the first pay toilets in history (Hughes, 1996).

${ }^{32}$ Urine was in demand by leather processors.
} 
One of these places that were literally frozen in time on that fateful day was the town of Herculaneum. Here the contents of the latrines have been preserved. The diet of the town's long-ago inhabitants is known for relatively broad, rich array of food; as many as 110 different types of food have been recorded (Robinson et Rowan, 2015). Of the osteological material contained in excrement forty-six fish species were recorded (most likely as a result of the proximity to the sea). It is a remarkable fact that fish were eaten whole-bones, head, and all. The findings also included egg shells. The palette of spices they consumed was also relatively rich, including celery seeds, coriander, fennel, black pepper imported from India, and fig seeds (Robinson et Rowan, 2015). The general popularity of fermented fish sauce, known as garum (or liquamen) throughout the entire ancient world was remarkable. One garum factory was discovered in Pompeii (Curtis, 1983), where the process of making must have been necessarily accompanied by a strong smell of rotting fish.

\section{Water Pollution $^{33}$}

All of the waste management measures examined here simply just shifted the problem somewhere else - the result was river pollution near urban areas (Hughes, 2014). Pliny the Elder comments upon this phenomenon in his Naturalis Historia: "... we dye even the rivers and the elemental substances of Nature, and turn the very means of life into a bane" (Plinius Maior, Nat. hist. 18.1.3, tr. Rackham). Waste was often thrown directly into rivers. Once Nero reportedly needed to draw attention away from the failures of his military campaigns. He wanted to show the people that Rome had a surplus supply of grain. Indeed, to hide his concern over events abroad, Nero had the common people's grain, which had rotted with age, dumped into the Tiber in order to maintain public confidence in the grain supply (Tacitus, Annales 15.18, transl. by Yardley). During the reign of this emperor, the bodies of victims of political purges were allegedly thrown into the Tiber: ... and they accompanied the putrefying corpses until they were dragged to the Tiber. There they floated around or were pushed to the banks by the current, and nobody cremated them or touched them (Tacitus, Annales 6.19, transl. by Yardley). As already mentioned, sewers often flowed into rivers without wastewater going under any kind of treatment. Galen (129-200 or 216) warns against eating fish from affected rivers: And some of them that dwell in rivers running through a large town, eating human dung and certain other bad food, are worst of all, as I said; so that even if they remain for a very short time after death, they straightaway become putrid and smell most unpleasantly. They are all unpleasant to eat and concoct and contain little nutriment but much residue. (Galenos, De alimentorum facultatibus 3.24.4, transl. by O. Powell) (Nonetheless, some perch species were considered to be delicacies.) Ritual drinking and bathing in the Tiber have also been documented (Weeber, 2006). From Imperial times, we have reports of cleaning the Tiber and widening its channel, already during the reign of Augustus: ... to control floods he widened and cleared the channel of the Tiber which had for a time been full of rubbish and narrowed by the encroachment of buildings (Suetonius, De vita ceasarum, Divus Augustus 30.1, trans. by D. Wardle). Such measures, however, were undertaken more to prevent flooding ${ }^{34}$ than to fight pollution itself. During Trajan's reign a sewerage administration office was established (Hughes, 2014: 176). Pliny the Younger, while serving as governor in the eastern part of the empire, reports to the same emperor on this problem in another city and an on a proposal for solving it: The city of the

\footnotetext{
${ }^{33}$ On this topic, see Weeber, 2006; Thüry, 2001: 45-49.

${ }^{34}$ For flooding on the Tiber, see ALDRETE, 2007.
} 
Amastrians, ${ }^{35}$ my lord, which is both smart and well appointed, has amongst its outstanding buildings a most beautiful and very extensive street. On its flank for its entire length runs a so-called river, but in reality it is the foulest of sewers. It is both unsightly in its most disgusting appearance and baneful in its most noisome smell. For these reasons it is in the interests of health as much as appearance that it should be covered over, and this will be carried out if you allow it, for we will see to it that money is not lacking for construction-work both massive and necessary. (Plinius Minor, Epistulae 10.98, transl. by P.G. Walsh). ${ }^{36}$ Another source of pollution were military camps; the later Roman author Vegetius gives advice for dealing with this problem, which, once again, merely circumvented the main problem: Neither should the army use bad or marsh water, for bad drinking-water, like poison, causes disease in the drinkers. ... If a multitude of soldiers stays too long in autumn or summer in the same place, then drinking-water contaminated by pollution of the water-supply and air tainted by the foul smell itself give rise to a most deadly disease. This can only be prevented by frequent changes of camp (Vegetius: De re militari 3.2, transl. by N. P. Milner).

\section{Air Pollution}

State authorities had to issue special public health protection regulations. One such example is a law preserved in the Codex Theodosianus (Jelínek et Kysučan, 2014).

"All of the lime kilns in the entire vicinity of the seacoast between the amphitheater and the port of the Divine Julian we order abolished, in the interest of the health of this enormous city and due to the proximity to our palace: no one shall be granted permission to burn lime in these places" (in Jelínek et Kysučan, 2014).

The amount of emissions from the open fires of tradesmen's street-side workshops, overpopulation, omnipresent noise, ${ }^{37}$ and the lax "Mediterranean" approach to hygiene must have made urban life in the hot summer months unbearable (Thüry, 2001). A lesser evil was the odor emanating from rotting waste itself, which was, again, primarily a problem in the summer. The smell of rubbish mixed with odors from other sources: Walking through the streets of Nero's Rome in the first century AD, one would encounter the stench of refuse rotting by the wayside, the piercing fragrance of burning myrrh emanating from temples, the heavy aroma of food being cooked by street vendors, the sweet, seductive scents of flowering gardens, tha malodour of rotting fish at a fishstand, the sharp smell of urine from a public latrine and perhaps the incense trail of a passing procession honouring a god or hero (Classen et al., 1994: 17).

A worse phenomenon was the increased occurrence of various pests founding favourable living conditions in such messy places. During the reign of Emperor Domitian (81 to 96), pollution in the city of Rome began to be taken seriously; the organized extermination of rats, lice, and bed bugs took place (Thüry 2001: 49-54).

The most visible effects of lax attitudes towards waste was the common occurrence of diseases such as cholera, typhus, dysentery, hepatitis, and polio (Weeber, 2006). The truth,

\footnotetext{
${ }^{35}$ Amastris in Paphlagonia (a territory on the northern coast of Asia Minor)— today's Amasra in Turkey.

${ }^{36}$ Trajan's response (epist. 10.99): My fondest Secundus, it is reasonable to have that water covered which flows through the city of the Amastrians, if by remaining uncovered it is a hindrance to health. I am certain that with your punctiliousness you will ensure that the money is not lacking for this work.

${ }^{37}$ In order to mitigate noise pollution, in many Roman towns wagons were prohibited from being used at night (Jelínek et Kysučan, 2014).
} 
however, remains that even with the development of hygienic regulations and measures in the ancient world the number of parasites such as flagellates and Ascaris lumbricoides did not decline in comparison with the preceding Iron Age (Mitchell, 2015).

Strong aromas and odors were just a part of daily life that the average citizen could simply not avoid. Air pollution in Rome was to a significant extent caused by heating homes with charcoal on the one hand, and the constant production of metals on the other hand, as well as from kilns of various types. When inversion kept a thick layer of smog and dust over the city, Romans called the occurrence "heavy skies" 38 (Hughes, 2001). Thus, from a certain perspective Rome might have seemed like an industrial city as we know them from the nineteenth century onward. We cannot superficially and romantically idealize any period in history.

\section{CONCLUSION}

It is hard to say whether we can identify with Lewis Mumford's comparison of life in ancient Rome to life in a sewer (Mumford, 1961: 215). In any case, in Roman towns waste was a significant problem. In material and written sources we can find direct and indirect evidence about the dirtiness of streets. Inhabitants had the custom of removing waste from their homes and workplaces and depositing it nearby. Town authorities tried to prevent this bad habit or tried to have existing waste removed. In general, however, there is no evidence of widespread municipal waste management in the modern sense of the word; there were only individual efforts at dealing with waste. Solid waste was deposited in dumps at the town's margins; liquid waste was flushed from the streets into the sewers, if it was not poured in directly. No strict differentiations were made, however. Sewers were also full of solid waste. In some places the existence of public latrines has been documented.

These measures most likely did not have the desired effect, although they were implemented throughout the entire existence of the Empire. A general awareness of the need for cleanliness seems to not have existed at all (Thommen, 2012: 128) and the extent of people's innate revulsion towards dirtiness was a highly individual phenomenon during the Roman era. We can expect this phenomenon particularly amongst the upper classes. Judd H. Alexander has put forth a remarkable hypothesis: the pollution, dirt, and smells of the city drove elites away to cleaner mountainous and coastal areas. This change led to the decentralization of power and de facto accelerated the creeping collapse of the entire empire (Alexander, 1993). This interesting observation, however, should only be viewed as one factor affecting social conditions during the Empire's downfall.

Moreover, the measures presented in this paper were more or less superficial solutions. The most important thing was that waste was not seen or smelt in eminent parts of the city. The problems were not removed; they were just moved elsewhere and continued to grow. The pollution of ground and surface water, contamination from dumps, and the disposal of waste in rivers were all significant problems. Emissions from burning materials also polluted the air.

The advancement of the Romans beyond other developed ancient cultures is up for debate and will require more thorough study. Organized waste management only began in the nineteenth century in some places, but only became widespread in the twentieth century. Instead of parallels, we can speak more about indications when it comes to Roman civilization.

\footnotetext{
${ }^{38}$ The extent of air pollution in the ancient world was so great that high concentrations of chemicals emitted between the first and fourth centuries BC can be found in Greenland's ice layers (Hong et al., 1994).
} 


\section{REFERENCES}

Alexander, J. H., (1993). In defense of garbage. Westport, CT: Praeger.

Aldrete, G. S., (2007). Floods of the Tiber in ancient Rome. JHU Press.

Adkins, L. et Adkins, R. A., (2004). Handbook to Life in Ancient Rome. Updated Edition. New York.

Bilitewski, B. B., Hardle, G., Marek, K., (1997). Waste Management. Springer. Berlin.

Blair, I., Spain, R., Swift, D., Taylor, T., \& Goodburn, D., (2006). Wells and bucket-chains: unforeseen elements of water supply in early Roman London. Britannia, 37, 1-52.

Classen, C., Howes, D., \& Synnott, A., (1994). Aroma: The cultural history of smell. Taylor $\&$ Francis.

Claridge, A., Toms, J., \& Cubberley, T., (1998). Rome: an Oxford archaeological guide. Oxford University Press.

Curtis, R. I., (Feb-Mar 1983). "In Defense of Garum". The Classical Journal 78 (3): 232 240.

Dawkins, R., (1999). The extended phenotype: The long reach of the gene. Oxford University Press.

Douglas, M., (1966). Purity and Danger. Analysis of the concepts of pollution and taboo. London.

Edwards, C., (2008). Lives of the Caesars. Oxford University Press.

Elias, N., (2000). The Civilizing Process. Sociogenetic and Psychogenetic Investigations. Revised edition. Oxford. Blackwell.

Evans, H. B., (1997). Water distribution in ancient Rome: The evidence of Frontinus. University of Michigan Press.

Glaser, F., (2006). Glaser Franz (Klagenfurt): "Canalization." Brill's New Pauly. Antiquity volumes edited by: Hubert Cancik and, Helmuth Schneider. Brill Online, 2015. Reference. Masaryk University - Masarykova. Retrieved October 20, 2015, from <http://referenceworks.brillonline.com/entries/brill-s-new-pauly/canalization-e608010> First appeared online: 2006.

Havlíček, F., (2015). Waste Management in Hunter-Gatherer Communities. Journal of Landscape Ecology (2015), Vol: 8 / No. 2.

Höcker, Ch. (2006). "Latrines." Brill's New Pauly. Antiquity volumes edited by: Hubert Cancik and Helmuth Schneider. Brill Online, 2015. Reference. Masaryk University Masarykova. Retrieved October 19, 2015, from <http://referenceworks. brillonline.com/entries/brill-s-new-pauly/latrines-e632530>First appeared online: 2006.

Hong, S., Candelone, J. P., Patterson, C. C., \& Boutron, C. F. ,(1994). Greenland ice evidence of hemispheric lead pollution two millennia ago by Greek and Roman civilizations. Science, 265(5180), 1841-1843.

Hopkins, J. N., (2007). The Cloaca Maxima and the monumental manipulation of water in archaic Rome. The Waters of Rome, 4, 1-15.

Hughes, J. D., (1996). Pan's Travail: Environmental Problems of the Ancient Greeks and Romans. Baltimore. Johns Hopkins University Press. 1996.

Hughes, J. D., (2001). An Environmental History of the World. Routledge. London.

Hughes, J. D., (2014). Environmental Problems of the Greeks and Romans: $2^{\text {nd }}$ edition. Ecology in the Ancient Mediterranean. Johns Hopkins University Press. 
Juvenal, (1967). The Sixteen Satires [by] Juvenal. Penguin.

Kelly, K., (1973). Garbage: the history and future of Garbage in America. Dutton Adult.

Korn, F. J., (2002). Hidden Rome. Paulist Press.

Jelínek, P., et Kysučan L., (2014). Venkov a krajina. Evropská krajina mezi venkovem a městem, mezi antikou a novověkem. (Countryside and landscape. The landscape between rural and urban, between antiquity and the modern era) MuniPress. Brno.

McLaughlin, T., (1973). Coprophilia, or, A Peck of Dirt. Cassell. London.

Mitchell, P. D., (2015). Sanitation, Latrines and Intestinal Parasites in Past Populations. Farnhame: Ashgate Publishing Ltd.

Milner, N.P. (1993). Vegetius: Epitome of Military Science. Liverpool: University Press, 1993.

Martialis, M. V., (1993). Epigrams. In (translated by DR Shackleton Bailey) Loeb Classical Library, 1.

Murdock, G. P., (1945). The common denominator of cultures. In R. Linton (Ed.), The science of man in world crisis. New York: Columbia University Press.

Mumford, L., (1961). The city in history: Its origins, its transformations, and its prospects. New York: Harcourt, Brace \& World.

Neudecker, R., (1994). Die Pracht der latrine. Zum Wandel öffentlicher Bedürfnisanstalten in der kaiserzeitlichen Stadt, 154-155.

Parslow, C., (1995). Rediscovering antiquity: Karl Weber and the excavation of Herculaneum, Pompeii, and Stabiae. Cambridge University Press.

Peña, J. T., (2007). Roman pottery in the archaeological record. Cambridge University Press.

Pichtel, J., (2005). Waste management practices: municipal, hazardous, and industrial. CRC Press.

Powell, O., \& Wilkins, J., (2003). Galen: On the properties of foodstuffs. Cambridge University Press.

Rackham, H., (1968). Pliny the Elder: Natural History, Loeb Classical Library.

Robinson, M. et Rowan, E., (2015). Roman Food Remains in Archaeology at the Contens of a Roman Sewer at Herculaneum. In A Companion to Food in the Ancient World, edited by John Wilkins and Robin Nadeau. London: Wiley-Blackwall.

Rodriguez Almeida, E., (1984). Il Monte Testaccio. Ambiente, storia, materiali.

Smith, V., (2007). Clean: a History of Personal Hygiene and Purity. Oxford University Press.

Tacitus, C., (2008). The Annals: The Reigns of Tiberius, Claudius, and Nero: The Reigns of Tiberius, Claudius, and Nero. Oxford University Press.

Thommen, L., (2012). An environmental history of ancient Greece and Rome. Cambridge University Press.

Thüry, G. E., (2001). Müll und Marmorsäulen. Siedlungshygiene in der Römischen Antike. Mainz: P. von Zabern.

Trevelyan, G. M., (1907). Garibaldi's Defence of the Roman Catholic Republic. Longmans, Green and Company.

Vesilind, P. A., Worrell, W., \& Reinhart, D., (2002). Solid waste engineering. Brooks/Cole. Pacific Grove. California USA. 
Walsh, P.G., (2006). Complete letters / Pliny the younger; translated with an introduction and notes by P.G. Walsh. Oxford: Oxford University Press, 2006.

Wardle, D., (2015). Suetonius: Life of Augustus. Oxford University Press.

Weeber, K. W., (2006). "Refuse." Brill's New Pauly. Antiquity volumes edited by: Hubert Cancik and Helmuth Schneider. Brill Online, 2015. Reference. Masaryk University Masarykova. Retrieved October 18, 2015, from <http://referenceworks. brillonline.com/entries/brill-s-new-pauly/refuse-e810890>First appeared online: 2006.

William, I., (1997). The Anatomy of Disgust. Cambridge, Mass. Harvard University Press.

Wexler, P., (2014). History of Toxicology and Environmental Health: Toxicology in Antiquity II. Academic Press. 


\section{APPENDIX}

Fig. 1: Public latrines in Ostia, Italy. Courtesy of Filip Havlíček, 2015

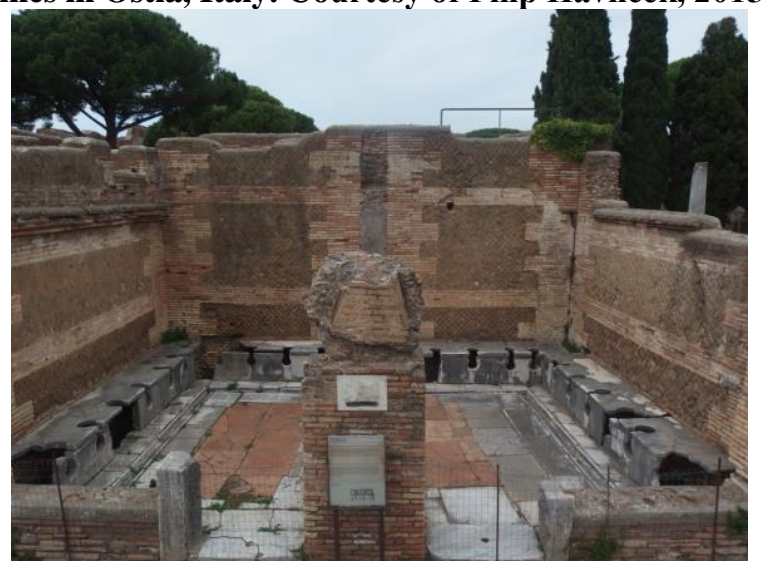

Fig. 2: Public latrines in Ostia, Italy. Courtesy of Filip Havlíček, 2015

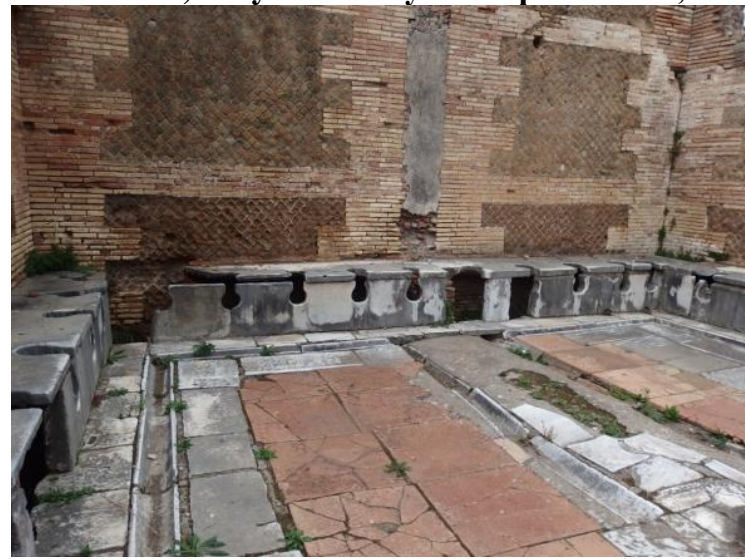

Fig. 3: Contemporary appearance of Cloaca Maxima sewer. Courtesy of Filip Havlíček, 2015

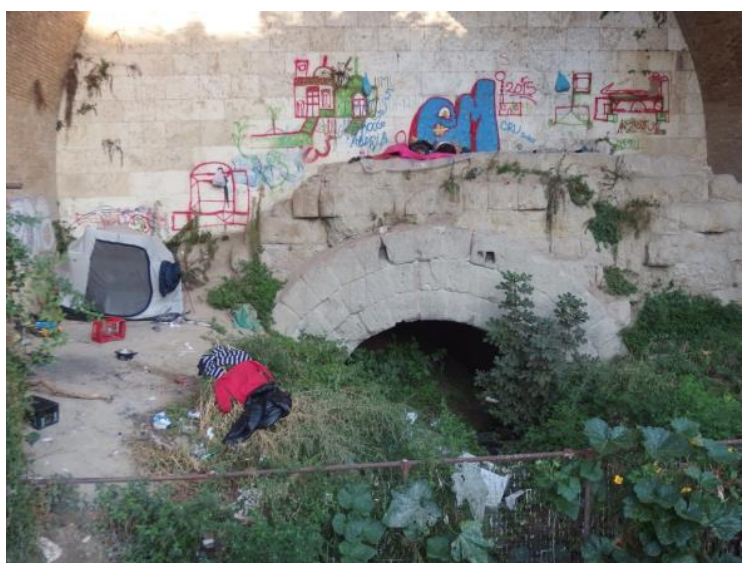


Fig. 4: Roman aqueduct. Courtesy of Filip Havlíček, 2015

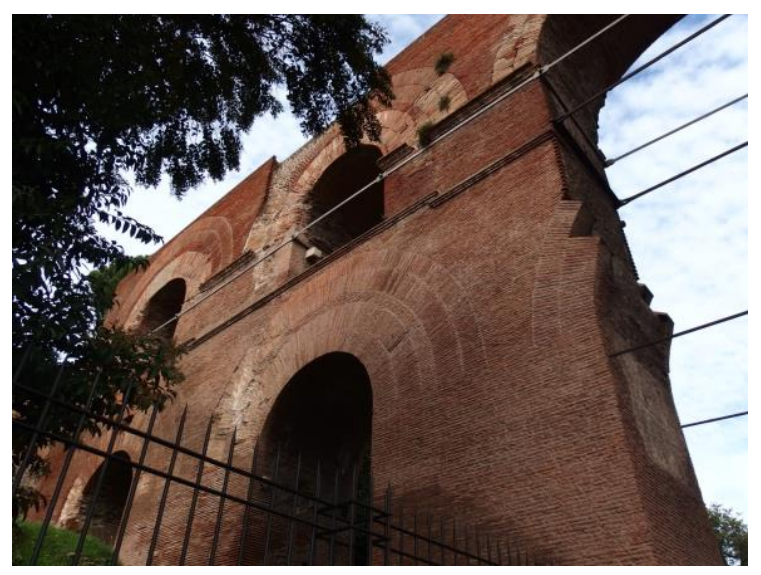

Fig. 5: Contemporary appearance of Monte Testaccio. Courtesy of Filip Havlíček, 2015

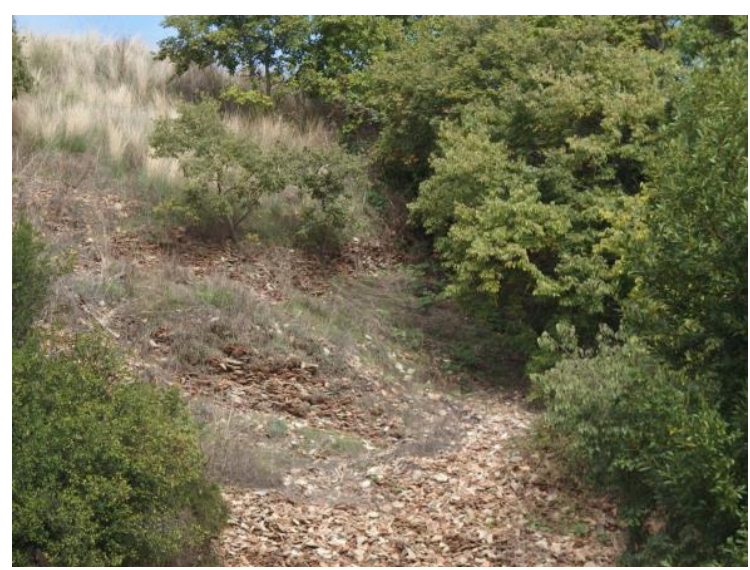

Fig. 6: Contemporary appearance of Monte Testaccio; profile with material deposits. Courtesy of Filip Havlíček, 2015

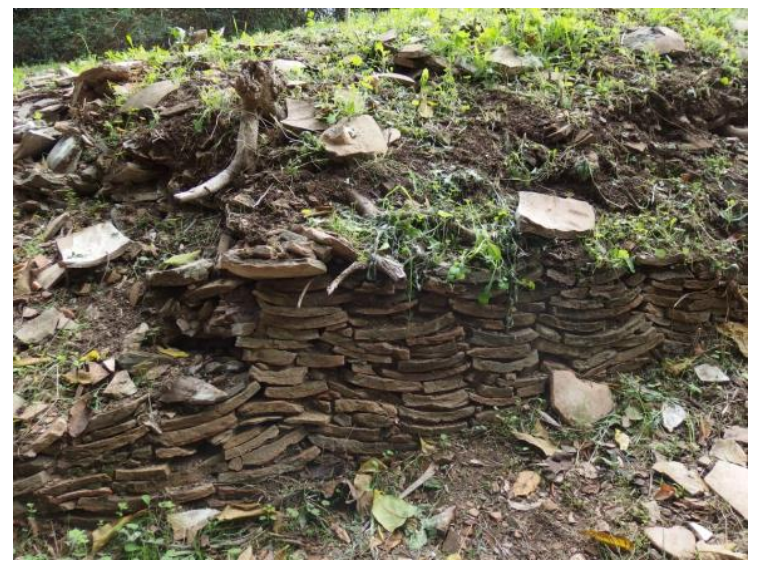


Fig. 7: Monte Testaccio - overall view of the waste heap. AUT Archivio Urbano Testaccio (in Rodriguez Almeida 1984)

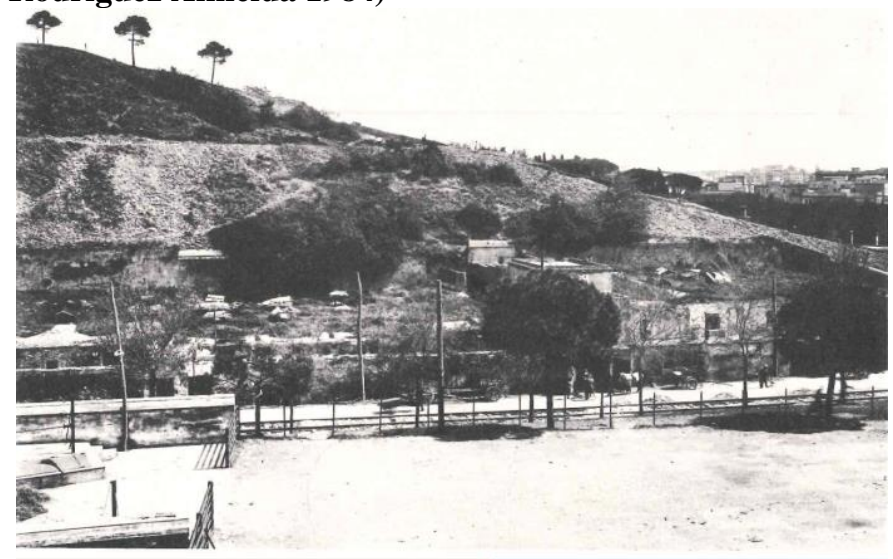

Fig. 8: Monte Testaccio - cross-section of the waste heap in one sector. AUT Archivio Urbano Testaccio in Rodriguez Almeida 1984)

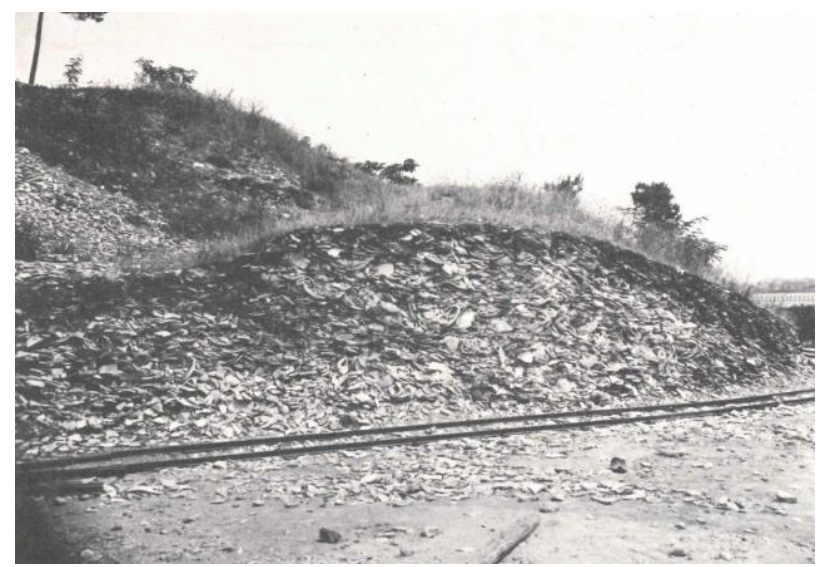

Fig. 9: Monte Testaccio - detail of a surface section from 1940. AUT Archivio Urbano Testaccio (in Rodriguez Almeida 1984)

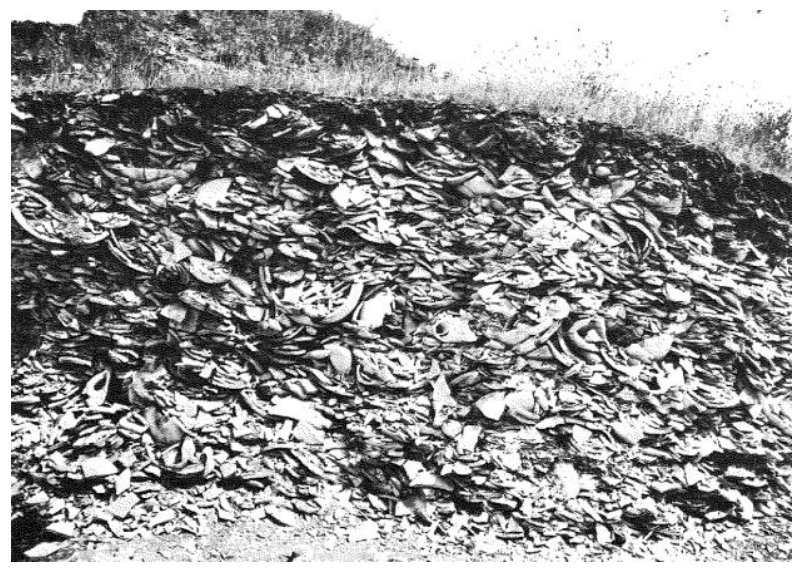

